\title{
A RESEARCH ON THE DETERMINATION OF THE FACTORS AFFECTING THE IMPLEMENTATIONS OF AGRICULTURAL INNOVATIONS BY BEEKEEPERS IN MUĞLA PROVINCE, TURKEY
}

\author{
ÇUKUR, T. ${ }^{*}-$ ÇUKUR, F. ${ }^{2}$ \\ ${ }^{1}$ Department of Marketing and Advertising, Milas Vocational School, Muğla Sitkı Koçman \\ University, 48200 Milas, Muğla, Turkey \\ ${ }^{2}$ Department of Management and Organization, Milas Vocational School, Muğla Sitkı Koçman \\ University, 48200 Milas, Muğla, Turkey \\ *Corresponding author \\ e-mail: tayfun.cukur@hotmail.com; phone: +90-252-211-3263; fax: +90-252-211-1879
}

(Received 22 $2^{\text {nd }}$ Mar 2019; accepted $13^{\text {th }}$ Jun 2019)

\begin{abstract}
This study aims to detect the factors which are effective on the adoption and the implementation of the agricultural innovations by the farmers who are focused on the beekeeping in the Milas district Muğla province of Turkey. For this aim, a questionnaire is made with 62 farmers who are determined with the method of proportional sampling. The method of Logistic Regression Analysis is used with the aim of the determination of the factors which are effective on the implementation of the innovations related to the beekeeping by farmers. According to the results of the analysis, it is determined that young farmers, farmers who have problems related to production, who are members of cooperative and who do not store the honey implement the agricultural innovations which are related to beekeeping more.
\end{abstract}

Keywords: beekeeping, agricultural extension, innovators, adoption, farmers

\section{Introduction}

The growing population in the world increases the demand for foodstuffs. No doubt, this situation creates a pressure on ecosystem. As it is not easy to increase the areas of agricultural production, it will be possible to meet the demand for foodstuffs by increasing the fertilization of agricultural production. The most important way of increasing agricultural fertilization is to develop modern agriculture technologies and agricultural innovations. As it known, agriculture is the most important source of income and livelihood for people who live in rural areas. For this reason, to be able to increase the fertilization, it is quite important to reach the developed technologies and agricultural innovations to the rural areas.

Rogers (1976) defines innovation as an idea, implementation or an object which is approved as new by an individual or a respective department. So, everything which the individual perceives for the first time has the characteristics of being new for that individual (Özçatalbaş and Gürgen, 1998). Some characteristics of innovations affect their adoption. General characteristics of innovations can be classified in five groups. These groups are; usefulness, suitability, simplicity, trialability and observability (Cinemre and Demiryürek, 2005).

Innovations are accepted as critical for socio-economic development as they contribute to the growth in industry, trade and economy in every society. Innovation contributes to the fertilization, productivity, quality and competitiveness (Mutsvangwa-Sammiea et al., 2018). The adoption of agricultural innovations is an important factor to increase 
agricultural fertilization, ensure food security, provide comprehensive growth and reduce poverty (Gebremariama and Tesfaye, 2018). The adoption of new technologies in terms of input and agricultural implementations has vital importance for the growth of agricultural sector. Together with the adoption of new technologies, the fertilization of land and labour force increases, natural sources are used effectively (Peter et al., 2018).

The time between the introduction of an innovation and the implementation of it is called "adoption process". Generally, the adoption of innovations takes time. It is detected that the adoption of innovations is not an instantaneous behaviour or act but a process which involves a series of acts and requires a specific time period. For example, the plantation of a new kind of a seed or the purchase and the use of a new drug when they are found out for the first time cannot be expected. Time is needed for this and this process sometimes lasts quite long (Cinemre and Demiryürek, 2005). All the individuals of rural population do not accept an innovation simultaneously. A part of the society becomes more eager in accepting and can adopt it years later when compared to the others (Özkaya, 1996).

One of the ways of minimizing the costs in businesses is to use new technologies which are effective on the cost. The implementation of technology in the businesses of husbandry hinges upon the degree of adoption of these innovations by the society in which these businesses take place (Türkyllmaz et al., 2003). The adoption and the propagation of innovations is a subject about which there are so many intensive debates and which does not lose its currency not only in agricultural area but also in branches such as health, marketing, business management, communication, sociology and geography (Aktaş, 2005).

Innovations in agricultural extension are new or improved inputs or methods which are handled in the process of agricultural production in an attempt to create behavioural change over farmers and obtain the desired result. The generalization of an innovation and making it be used by so many farmers can be possible by carrying out various agricultural extension activities effectively and within a long time period.

Agricultural innovation is not just a matter of adopting new technologies. It also necessitates a balance between the new techniques and alternative organization types (Klerks et al., 2012). It is accepted that the decision of adopting innovations is correlated with the social, economical and psychological characteristics of potential adopters. In adopting the innovations, not only the characteristics of the individuals but also the characteristics of the innovation are important (Longo, 1990). Adopting agricultural technologies is a complicated process because of the multidimensional nature of the technologies and mutual relations between the different explanatory factors (Jensen et al., 2014). The characteristics of the farmer and the agricultural enterprise, bio-physical characteristics of the agricultural enterprise, financial and administrative characteristics of the agricultural enterprise and the other factors occurring out of the farmers are effective on the decision of adopting new technology (Yigezu et al., 2018). When the litterateur is examined, it is seen that a great number of factors are effective on the adoption of the innovations by farmers.

Beekeeping is not seen as a source of side income for agricultural businesses any more rather it is seen as a main income source. Turkey occupies the first places in the world in terms of both the bee possession and the production of bee products. According to the 2018 data, the number of the beekeeping businesses in Turkey is 81.300 and the number of hives is 8.108.424. In 2018, the total amount of honey produced is 107.920 tons and the total amount of beeswax is 3.987 tons (TÜIK, 2018). 
The aim of this study is to determine the implementation circumstances of innovations by farmers who are focused on beekeeping in the Milas district. In this context, the factors which are effective on the decisions of the farmers in terms of implementing innovations will be detected by examining the circumstances of following and implementing the innovations by farmers.

\section{Materials and Methods}

The primary material of the study composes of 62 questionnaires which are made with the farmers in 9 villages in the Milas district in Muğla province. Moreover, the previous research on the subject has been capitalized on to a great extent. The questionnaires were administered in April-May 2017.

In this study, purposive sampling method is used in choosing the villages with which the questionnaire is made. The study of questionnaire is made in 9 villages composing of Karahayıt, Sakarkaya, Akçalı, Çukurköy, Gölyaka, Kapıkırı, Fesleğen, Kalem and Karacahisar in which beekeeping is performed intensively in the Milas district Muğla province of Turkey (Figure 1).



Figure 1. Map of Muğla Province (Source: Anonymous, 2004)

According to the information taken from Milas Agriculture and Forestry District Directorate, 721 farmers perform beekeeping activities in the district and these 721 farmers constitute the main population of the study (Anonymous, 2017). In the research, farmers who are determined with the proportional sample size are interviewed (Newbold, 1995). 90\% confidence interval and 10\% error margin are grounded on in the research. In Equation 1; $\mathrm{n}$ is the sample size, $\mathrm{N}$ is the population size, $\mathrm{p}$ is the ratio of the studied feature in the main population (the ratio of the beekeepers who implement innovations is accepted as $50 \%$ as it is desired to reach the maximum sample size and $\mathrm{p}=0.5$ is taken).

$$
n=\frac{N p(1-p)}{(N-1) \sigma_{P}^{2}+p(1-p)}
$$


According to the calculation, the total number of the farmers who are to be interviewed is calculated as 62. The range of the applied questionnaires according to the districts is given on Table 1.

Table 1. Villagers with whom the questionnaire is made in the scope of the research

\begin{tabular}{c|c}
\hline Villages & Beekeepers with whom the questionnaire is made (n) \\
\hline Karahayıt & 5 \\
Sakarkaya & 12 \\
Akçalı & 15 \\
Çukurköy & 13 \\
Kapıkırı & 3 \\
Gölyaka & 2 \\
Fesleğen & 6 \\
Kalem & 2 \\
Karacahisar & 4 \\
\hline TOTAL & 62 \\
\hline
\end{tabular}

Logistic regression analysis method is used in the research with the aim of determining the factors which are effective on the circumstances of adopting the innovations by farmers. The aim of the model is to create the most suitable model by also paying regard to the level of the relation between the dependent variable and the independent variable or variables when the dependent variable (Y) is bivalent or classified (Önder and Cebeci, 2002). Logistic regression is a method from which is benefited in detecting the cause and effect relation with explanatory variable when categorically; the response variable is observed in dual, trio and multiple categories. It is a regression method which helps perform the classification and appointment transactions in which the expected value of response variable is obtained as probability in accordance with the explanatory variables (Everest, 2015).

Logistic regression does not deal with estimating the value of dependent variable. Instead of this, the probability of taking the value of 1 of dependent variable is tried to be estimated. As the obtained result is a value of a probability, it can only take values between 0 and 1 (Alpar, 2011). The model of logistic regression estimates the result as any value between 0 and 1 and tries to detect the probability of being 1 of dependent variable (Hosmer and Lemeshow, 2000). The logistic regression model used in the study is given in the Equation 2.

$$
\pi(x)=P(Y=1 / X=x)=\frac{e^{\beta_{0}+\beta_{1} X_{1}+\beta_{2} X_{2}+\ldots+\beta_{p} X_{p}}}{1+e^{\beta_{0}+\beta_{1} X_{1}+\beta_{2} X_{2}+\ldots+\beta_{p} X_{p}}}=\frac{1}{1+e^{-\left(\beta_{0}+\beta_{1} X_{1}+\beta_{2} X_{2}+\ldots+\beta_{p} X_{p}\right)}}
$$

where $X$ : is the data matrix in relation to the independent variable and $X=x$ is (when the value of $X$ is known) the probability of the occurrence of the event $(Y=1) \pi$. $\beta=$ refers to constant, $\beta \mathrm{i}=$ refers to the to be estimated parameter for every explanatory (independent) variable, $\mathrm{Xi}=$ refers to the $\mathrm{i}^{\mathrm{th}}$ independent variable. Logit conversion is applied to the logistic regression function which is given in the equilibrium and is not linear and it is linearized. When the model is fixed according to the datas of the study, Equation 3 is formed. Accordingly, b1 shows how much alteration 1 unit alteration in independent variable $\mathrm{x}$ causes in dependent variable (Aldrich and Nelson, 1984). 


$$
g(x)=\operatorname{In}\left[\frac{\pi(x)}{(1-\pi(x))}\right]=\operatorname{In} e^{\beta_{0}+\beta_{1} X}=\beta_{0}+\beta_{1} X \ldots
$$

In the research, a model which can identify the relation between the dependent and independent variables by using the least variables to have the best accord and which can be accepted as true statistically is established (Ertan and Gök, 2012). The farmers who implement the innovations related to beekeeping are coded as 1 and the farmers who do not implement the innovations are coded as 0 . The functional form of the regression model estimating the factors which are effective on the adoption of the agricultural innovations by beekeepers is as in the following.

$\mathrm{Y}=\mathrm{f}(\mathrm{X} 1, \mathrm{X} 2, \mathrm{X} 3, \mathrm{X} 4, \mathrm{X} 5, \mathrm{X} 6, \mathrm{X} 7, \mathrm{X} 8, \mathrm{X} 9, \mathrm{X} 10, \mathrm{X} 11, \mathrm{X} 12, \mathrm{X} 13)$

Y; The circumstance of implementing the agricultural innovations yes; 1, no; 0 (Dummy).

$\mathrm{X} 1$; The age of the business manager.

$\mathrm{X} 2$; Educational level of the business manager.

$\mathrm{X} 3$; Beekeeping experience of the business manager.

$\mathrm{X} 4$; The amount of honey production.

$\mathrm{X} 5$; The circumstance of the business managers to get a loan yes; 1, no; 0 (Dummy).

X6; The circumstance of record keeping of the business yes; 1, no; 0 (Dummy).

X7; The circumstance of the business managers to have the information about the domestic market yes; 1, no; 0 (Dummy).

$\mathrm{X} 8$; The circumstance of the business managers to have the information about the foreign market yes; 1, no; 0 (Dummy).

X9; The circumstance of the business managers to have a problem about the production of bee products yes; 1, no; 0 (Dummy).

$\mathrm{X} 10$; The circumstance of the business managers to have a problem about the marketing of bee products yes; 1 , no; 0 (Dummy).

$\mathrm{X} 11$; The circumstance of the business managers to be a member of the cooperative yes; 1, no; 0 (Dummy).

$\mathrm{X} 12$; The storage circumstance of the produced honey yes; 1, no; 0 (Dummy).

$\mathrm{X} 13$; The circumstance of participation in agriculture fairs yes; 1, no; 0 (Dummy).

\section{Results}

\section{Socio-economical characteristics of beekeepers}

The socio-economical characteristics of the farmers have important effects on their adoption of the innovations. Therefore, socio-economical characteristics of the beekeepers are examined. The ages, time periods of agricultural experience, time periods of beekeeping experience, education levels of the beekeepers, the number of hives and the sources of income take place among the socio-economical characteristics which are examined in the research.

It is detected that $41.94 \%$ of the producers are older than $51,50 \%$ of the producers are at the age of $35-50$ and $8.06 \%$ are younger than 35 . As it is seen from these results, half of the beekeepers are at the age range of 35-50. The age average of the beekeepers is found as 48 . It is seen that $61.29 \%$ of the beekeepers have the experience of agriculture for more than 21 years. It is detected that $12.90 \%$ of the beekeepers deal with the 
agricultural production for less than 10 years, $25.81 \%$ of the beekeepers deal with the agricultural production for 10-20 years. It is seen that $45.16 \%$ of beekeepers have had the experience about beekeeping for more than 21 years. It is detected that $32.26 \%$ of beekeepers perform beekeeping for less than 10 years and $22.58 \%$ of beekeepers perform beekeeping for 10-20 years. It can be stated that the level of education can be effective on the information sources that the farmers who perform beekeeping use. According to the datas of the questionnaire, it can be said that the majority of the beekeepers are the graduates of primary school (80.65\%). $14.52 \%$ of the beekeepers are the graduates of secondary/high school and one beekeeper is the graduate of college. It is detected that $33.87 \%$ of the beekeepers have less than 100 hives, $40.32 \%$ of beekeepers have 100-200 hives and $25.81 \%$ of beekeepers have more than 201 hives. It is seen that $74.19 \%$ of the beekeepers earn their lives only with agriculture and $25.81 \%$ of the beekeepers, together with agriculture, deal with some other job activities out of agriculture (Table 2).

Table 2. Socio-economic characteristics of beekeepers

\begin{tabular}{|c|c|c|}
\hline Variables & Number & $\%$ \\
\hline \multicolumn{3}{|l|}{ Age } \\
\hline$<35$ & 5 & 8.06 \\
\hline $35-50$ & 31 & 50.00 \\
\hline $51+$ & 26 & 41.94 \\
\hline \multicolumn{3}{|c|}{ The duration of agricultural experience (year) } \\
\hline$<10$ & 8 & 12.90 \\
\hline $10-20$ & 16 & 25.81 \\
\hline $21+$ & 38 & 61.29 \\
\hline \multicolumn{3}{|c|}{ The duration of beekeeping experience (year) } \\
\hline$<10$ & 20 & 32.26 \\
\hline $10-20$ & 14 & 22.58 \\
\hline $21+$ & 28 & 45.16 \\
\hline \multicolumn{3}{|l|}{ Education } \\
\hline Literate & 2 & 3.22 \\
\hline Primary School & 50 & 80.65 \\
\hline Secondary-High School & 9 & 14.52 \\
\hline College & 1 & 1.61 \\
\hline \multicolumn{3}{|l|}{ The number of hives } \\
\hline$<100$ & 21 & 33.87 \\
\hline $100-200$ & 25 & 40.32 \\
\hline $201+$ & 16 & 25.81 \\
\hline \multicolumn{3}{|l|}{ Sources of income } \\
\hline Agriculture & 46 & 74.19 \\
\hline Agriculture+non-agricultural & 16 & 25.81 \\
\hline
\end{tabular}

\section{The information needs and the information sources of farmers about beekeeping}

Rogers states that innovations are adopted at five stages (Rogers, 1983). These stages are: awareness, interest, evaluation, trial and adoption. Farmers need information quite intensively especially at the stages of awareness and interest. Therefore, it is vital that the needs for the information should be detected for farmers to decide about innovation and these needs should be met, the information should be provided truly and on time for the farmers to adopt the agricultural innovations.

In the current study, it was found that the beekeepers are in need of information about various subjects related to beekeeping. It was determined that $79 \%$ of the farmers who took place in the research need information about beekeeping. The major need for information is about disease and pest control. $64.5 \%$ of the farmers need information 


$$
\text { - } 10889 \text { - }
$$

about disease and pest control. 32.3\% of the farmers need information about marketing and $27.4 \%$ of the farmers need information about bee production (Table 3).

Table 3. The subjects that the farmers need information about beekeeping

\begin{tabular}{c|c|c}
\hline & $\mathbf{n}$ & $\mathbf{\%}$ \\
\hline Disease and pest control & 40 & 64.5 \\
Marketing & 20 & 32.3 \\
Queen bee production & 17 & 27.4 \\
The production of bee products & 16 & 25.8 \\
Management of colony & 14 & 22.6 \\
Agricultural supports & 12 & 19.4 \\
Subjects about farmer organization & 7 & 11.3 \\
The storage of bee products & 1 & 1.6 \\
Social and cultural subjects & 1 & 1.6 \\
Giving sugar and the time for it & 1 & 1.6 \\
\hline
\end{tabular}

*The total is over $100 \%$ as there are answers more than one

Information sources play an important role over getting into touch with new technologies, being aware of the information, creating an interest, making understanding easy and encouraging farmers to adopt (Pandey, 2014). In the study, it was determined that the beekeepers obtain information from different sources. In the research, Agriculture and Forestry District Directorate comes first as an information source of the farmers (38.7\%). $37.1 \%$ of the farmers consult to the union of beekeepers and $24.2 \%$ of the farmers consult to their friends and relatives (Table 4).

Table 4. Information sources of the farmers

\begin{tabular}{c|c|c}
\hline & $\mathbf{n}$ & $\mathbf{\%}$ \\
\hline Agriculture and Forestry District Directorate & 24 & 38.7 \\
The Union of Beekeepers & 23 & 37.1 \\
Friends and relatives & 15 & 24.2 \\
Veterinary & 8 & 12.9 \\
I do not consult anybody & 4 & 6.5 \\
Internet & 1 & 1.6 \\
Municipality & 1 & 1.6 \\
The head of village or neighborhood & 1 & 1.6 \\
\hline
\end{tabular}

*The total is over $100 \%$ as there are answers more than one

\section{The points of view of farmers towards agricultural extension}

Innovativeness which is an adoption and implementation of an idea in a society for the first time is really important for the extension of the innovations. The aim in agricultural extension is to increase the number of innovators (Cinemre and Demiryürek, 2005). For this reason, the determination of the points of view of the farmers towards agricultural extension/extensionists is quite important as the agricultural extension/extensionists play an important role in the access and the implementation of innovations by farmers. Because the more powerful is the relation between the farmer and extensionist, the more high is the possibility of adopting the innovations by farmers. In the study, it was found that the beekeepers are not much in contact with extensionists. While $22.6 \%$ of farmers state that they do not get into touch with the extensionists, $53.2 \%$ of the farmers state that 
they get into touch with the extensionists twice a year (Table 5). While $89.6 \%$ of the producers (48 producers) who state that they get into touch with the extensionists for the aim of getting information find the information that they get useful, $10.4 \%$ of the producers does not find the information useful.

Table 5. The frequency of getting into touch with extensionists by farmers for the aim of getting information about beekeeping

\begin{tabular}{c|c|c}
\hline & $\mathbf{n}$ & $\mathbf{\%}$ \\
\hline Once a week & 1 & 1.6 \\
Once a month & 6 & 9.7 \\
Once in three months & 5 & 8.1 \\
Once a year & 2 & 3.2 \\
Twice a year & 33 & 53.2 \\
Thrice a year & 1 & 1.6 \\
I do not get into touch & 14 & 22.6 \\
\hline Total & 62 & 100.0 \\
\hline
\end{tabular}

It can be argued that the beekeepers' contacts with extensionists generally occur in the village. The proportion of the farmers who say that "I get into touch with the extensionists when they come to the village" is found as $45.2 \%$ on the other hand, the proportion of the farmers who say that "I get into touch with the extensionists when I have a problem" is found as $32.3 \%$ (Table 6). $22.6 \%$ of the farmers states that they never get into touch with the extensionists.

Table 6. The circumstance of getting into touch with the extensionists

\begin{tabular}{c|c|c}
\hline & $\mathbf{n}$ & \% \\
\hline I get into touch with the extensionists when I have a problem & 20 & 32.3 \\
I get into touch with the extensionists when they come to the village & 28 & 45.1 \\
I never get into touch & 14 & 22.6 \\
\hline
\end{tabular}

When the places where the beekeepers and extensionists get in contact were examined, it was found that nearly half of the contacts occurred in the tea house of the village. With a proportion of $45.2 \%$, the village's tea house comes first for the farmers as a place for getting into touch with extensionists. The proportion of the farmers who state that they get into touch with the extensionists at Agriculture and Forestry District Directorate is detected as $45.2 \%$ (Table 7).

It can be stated that mass communication is effective on the adoption of innovations. The most important reason of this is that the attentions of the farmers can be drawn to the innovation and a specific level of knowledge about innovation can be created (Sezgin, 2010). It is detected in the research that $91.9 \%$ of the farmers watch agriculture programmes at the television while $37.1 \%$ of the farmers listen to the agricultural programmes at the radio. $59.7 \%$ of the farmers state that they read books, magazines and newspapers about agriculture. In the research, the proportion of the farmers who use internet for agricultural purposes is found as $24.2 \%$ (Table 8 ).

Demonstrations show a group that how a new work is done or how an old work is done better (Cinemre and Demiryürek, 2005). Demonstrations are some of the extension methods which enable farmers to learn by hearing, seeing and practicing. Demonstrations are accepted as the most effective method at the operations of agricultural extension and 
they are used quite prevalently (Yurttaş and Atsan, 2007). In the research, the proportion of the farmers who attend the demonstrations about beekeeping is found as $16.1 \%$. While the proportion the farmers who attend the course/seminar about beekeeping is detected as $24.2 \%$, the proportion of the farmers who attend conference/panel activities is detected as $40.3 \%$ (Table 8 ).

Table 7. The place of getting into touch with the extensionists by farmers

\begin{tabular}{|c|c|c|}
\hline & n* & $\%$ \\
\hline Agriculture and Forestry District Directorate & 28 & 45.2 \\
\hline Village chamber & 4 & 6.5 \\
\hline Village's tea house & 30 & 48.4 \\
\hline Terrain & 2 & 3.2 \\
\hline Telephone & 2 & 3.2 \\
\hline I get into touch at the meetings organized & 8 & 12.9 \\
\hline I never get into touch & 14 & 22.6 \\
\hline
\end{tabular}

*The total is over $100 \%$ as there are answers more than one

Table 8. The circumstances of the farmers to attend various activities

\begin{tabular}{c|c|c}
\hline & n & \% \\
\hline Watching agriculture programmes at television & 57 & 91.9 \\
Attending agriculture fairs and exhibitions & 39 & 62.9 \\
Reading materials like book, magazine, newspaper, leaflet etc. about agriculture & 37 & 59.7 \\
Being informed via telephone or sms about agriculture & 34 & 54.8 \\
Attending the farm or home visits & 26 & 41.9 \\
Attending the conference-panel activities & 25 & 40.3 \\
Listening to the programmes about agriculture at the radio & 23 & 37.1 \\
Using internet with the aim of agriculture & 15 & 24.2 \\
Attending course-seminar activities & 15 & 24.2 \\
Attending demonstration activities & 10 & 16.1 \\
Attending the trips with the aim of agriculture & 6 & 9.7 \\
Attending the competitions with the aim of agriculture & 2 & 3.2 \\
\hline
\end{tabular}

Agriculture fairs are important agricultural activities which provide information to the farmers about the new techniques and technologies in the agricultural sector. Farmers find the possibility to practice the new technology instantly thanks to the demonstration areas created at the fairs (Çukur and Çukur, 2017). It is detected in the research that $62.9 \%$ of the farmers attend the agriculture fairs and exhibitions (Table 8).

\section{Results of Logistic Regression Analysis}

The proportion of the farmers who state that they follow the innovations about beekeeping is found as $69.4 \%$. 61.3\% of the farmers state that they implement the innovations about beekeeping.

The ages of the farmers, the circumstances of the farmers to have a problem about production and the circumstances of them to be a member of a cooperative are found significant at 0.05 level of significance and the circumstance of storing the honey is found significant at 0.10 level of significance statistically, at the logistic regression analysis which is done for the aim of the determination of the factors which are effective on the implementations of agricultural innovations about beekeeping by farmers. That is, it is determined that young farmers, farmers who have problems related to production, who 
are the members of the cooperative and who do not store the honey implement the agricultural innovations about beekeeping more (Table 9).

Table 9. Logistic Regression Results

\begin{tabular}{c|c|c|c}
\hline INNOVATION & Coef. & Std. Err. & $\mathbf{P}>|\mathbf{z}|$ \\
\hline Age & -0.1149346 & 0.0535188 & $\mathbf{0 . 0 3 2}$ \\
Education & -0.1166394 & 0.203393 & 0.566 \\
Experience & 0.0248924 & 0.0445552 & 0.576 \\
Production & 0.0000635 & 0.0001996 & 0.750 \\
Credit & 0.5355139 & 0.7737263 & 0.489 \\
Record & -0.8402401 & 1.174613 & 0.474 \\
Domestic & -0.8161603 & 0.8246815 & 0.322 \\
Foreign & -0.2167684 & 0.9579789 & 0.821 \\
Proprob & 2.577754 & 1.233063 & $\mathbf{0 . 0 3 7}$ \\
Marprob & 0.6426032 & 1.028957 & 0.532 \\
Coop & 1.543304 & 0.7792494 & $\mathbf{0 . 0 4 8}$ \\
Storage & -1.438156 & 0.7846837 & $\mathbf{0 . 0 6 7}$ \\
Fair & 0.7029553 & 0.7998101 & 0.379 \\
Cons & 3.160572 & 3.32936 & 0.342 \\
Log likelihood $=-28.575797$ & & \\
Number of obs $=61$ & & & \\
Prob chi ${ }^{2}(13)$ chi ${ }^{2}=0.0341$ & & &
\end{tabular}

\section{Discussion}

In this study which aims to determine the implementation of innovations by farmers who perform beekeeping at the district of Milas, it is determined that a great deal of the farmers adopt and implement the innovations about beekeeping (61.3\%). In the research which is done by Kızılaslan and Ünal (2013), similar results are found and it is determined that $67.2 \%$ of the farmers implement the new agricultural informations and techniques. According to the research done by Kizılaslan (2009), the proportion of the farmers who state that they sometimes implement the innovations is detected as $71.67 \%$. On the other hand, according to the research done by Özçatalbaş (2000), it is detected that the level of adopting the innovations at the majority of producers is under the level of intermediate and the proportion of the producers who have high adopting level is $8.7 \%$. In the research done by Udofia and Edet (2016) at Ethiopia, the proportion of adopting the modern beekeeping techniques by beekeepers is found quite low and it is determined that only $16.80 \%$ of the beekeepers adopt modern beekeeping techniques. According to the research done by Chambo et al. (2018), more than half of the beekeepers adopt more than $74 \%$ of the suggestions about the harvest and after harvest. According to the research done by Kumar (2013), farmers adopt $45.71 \%$ of the innovations about bee feeding and $36.66 \%$ of the innovations about migratory beekeeping. These proportional differences occurring between the levels of adopting the innovations can arise from the differences at the personal characteristics of the beekeepers, social structure and the economical and financial situations of the beekeepers.

As there are differences between the levels of adopting the innovations by beekeepers, there are also differences in the factors which are effective on the adoption of the 
innovations. In this study, it is detected that young farmers, farmers who have problems related to production, who are the members of the cooperative and who do not store the honey implement the agricultural innovations related to beekeeping more. According to the research done by Wodajo (2011), getting loan, the education level of the father of the family and attending the demonstrations have positive effects on the adoption of modern hives by farmers. In the research done by Adgaba et al. (2014), it is determined that farmers who have a crowded family, who have a high level of education and young farmers adopt the usage of modern hives more easily.

One of the most important factors in adopting the agricultural innovations by farmers is, no doubt, the practices of agricultural extension. In the research done by Fadare et al. (2008), it is detected that the proportion of adopting the innovations by beekeepers is low and the greatest reason of this is the low level of relation between the farmer and extensionist. According to the findings obtained from the research, it can be said that farmers do not get into touch with the extensionists very often. It is detected in the research that $53.2 \%$ of the beekeepers get into touch with the extensionists twice a year. In the research done by Ahmad et al. (2007), the majority of the farmers (82.5\%) do not visit the local agricultural extension office. In the research done by Jan et al. (2008), the proportion of the farmers who says that "last year, extensionist came to the place that I live" is found as just $2.5 \%$. In the research done by Kenea (2008) in Kenya, it is determined that $58.8 \%$ of the farmers did not get into touch with the extensionists last year, $38.8 \%$ of the farmers get into touch with the extensionists at least once a year and $8.5 \%$ of the farmers get into touch with the extensionists at least once a month.

The age of the owners of the business is an important factor in adopting the innovations. It is determined at the end of the research that the level of adopting the innovations by young farmers is higher and this result shows a parallelism with the data of litterateur. In the research done by Boz et al. (2011) and Sezgin et al. (2010), it is determined that there is an important relation between the age and the adoption of innovations.

In the research, it is determined that being a member of the cooperative has an important effect on the adoption of agricultural innovations by farmers. In the research done by Kolade and Harpham (2014) and Wossen et al. (2017), the same result is detected.

It is detected that an important part of the farmers (89.6\%) finds the information that they get from the extensionist useful. In the research done by Apantaku et al. (2016), same results are found and it is detected that $53 \%$ of the farmers think that agricultural extension services develop the agricultural activities, $94 \%$ of the farmers think that agricultural extension services help farmers be educated about the better agricultural techniques. According to the research done by Muktar et al. (2016) in Nigeria, 10\% of the farmers find the agricultural extension quite useful in terms of their production, $8.8 \%$ of the farmers find it useful and $45 \%$ of the farmers find it partially useful. In the research done by Yalçın and Boz (2007), it is emphasized that the importance of district and provincial directorates of agriculture, in terms of extension, decreases in the region.

First of all, farmers need to get true and confidential information about innovation to be able to adopt the innovations. It is detected in the research that an important part of the beekeepers needs information about illness and pest control and marketing. Similarly, in the research done by Sıralı and Doğaroğlu (2004), it is determined that $45.94 \%$ of beekeepers needs information about illness, pest and the control of them. According to the research done by Awino et al. (2018), farmers need information about the illnesses 
and pests which affect the bees and producing and marketing the bee products. In the research done by Ibegbulem (2014), it is stated that farmers need information about the sources of the plants on which the bees gather pollens.

Today, farmers use mass communication (television, radio, internet, newspaper, book, magazine etc.) quite intensively to be informed about agricultural innovations and get information about new technologies. In the research, the proportion of watching agricultural programmes at television by farmers is found high and the proportion of listening to the programmes about agriculture is found relatively low. It is determined in the research done by Ahmad et al. (2007) that the proportion of farmers who regard radio as an information source is $83.75 \%$ and the proportion of farmers who regard television as an information source is $82.50 \%$. In the research done by Akinbile and Alabi (2010), the proportion of the farmers who listen to the radio to update their knowledge is found as $75 \%$ and the proportion of the farmers who watch television to update their knowledge is found as 69.2\%. In the research done by Anastasios et al. (2010) in Greece, it is detected that $80.41 \%$ of the farmers have television. According to the research done by Sezgin (2010), $41.4 \%$ of the farmers follow the programmes about agriculture at television/radio regularly.

$59.7 \%$ of the farmers state that they read books, magazines and newspapers about agriculture. Similar results are found in the research done by and the proportion of the farmers who read newspaper is found as $61.7 \%$. In the research done by Ijatuyi (2016) in Nigeria, it is detected that $18.75 \%$ of the farmers regard newspaper as a source of information. In the research done by Wangu (2014), it is detected that $30.6 \%$ of the farmers regard newspaper as a source of information and $9.2 \%$ of the farmers regard agricultural magazines as a source of information.

Approximately one fourth of the farmers who join in the research use internet for the aim of agriculture. Similar results are found in the research done by Okwu and Iorkaa (2011) and the proportion of the farmers who use internet for the aim of getting information is found as 23.9\%. In the research done by Akinbile and Alabi (2010), the proportion of the farmers who use internet for the aim of getting information is found a bit low as $11.7 \%$. In the research done by Anastasios et al. (2010) the proportion of the farmers who use the internet is found as $15.10 \%$.

\section{Conclusion}

Consequently, the managers of the businesses should be young, the member of the cooperative and the farmers who do not store the honey to adopt and implement the innovations faster in the businesses of beekeeping in the district of Milas in Muğla province and accordingly, to perform a more fertile and profitable beekeeping by using modern agricultural techniques and technologies. Besides this, it should be remembered that the farmers who have a high level of information about agriculture, who are open to the innovations and the outer world and who trust the extensionists contribute to the development of beekeeping more. For this reason, performing the agricultural extension activities with the aim of increasing the levels of innovativeness of the beekeepers by considering their present situation is thought to be quite useful. 


\section{REFERENCES}

[1] Adgaba, N., Al-Ghamdi, A., Shenkute, A. G., Ismaiel, S., Al-Kahtani, S., Tadess, Y., Ansari, M. J., Abebe, W., Abdulaziz, M. Q. A. (2014): Socio-economic analysis of beekeeping and determinants of box hive technology adoption in the Kingdom of Saudi Arabia. - The J. of Animal \& Plant Sciences 24(6): 1876-1884.

[2] Ahmad, M., Ahmad, M., Akram, M., Rauf, R., Khan, I. A., Pervez, U. (2007): Interaction of extension worker with farmers and role of radio and television as sources of information in technology transfer: a case study of four villages of district Peshawar and Charsadda. Sarhad J. Agric. 23(2): 515-518.

[3] Akinbile, L. A., Alabi, O. E. (2010): Use of ICTs among fish farmers in Oyo state. - Journal of Agricultural Extension 14(1): 22-30.

[4] Aktaş, Y. (2005): Entrance of Agricultural Extension and Communication. - Dilara Publishing House, Trabzon, 283p. (in Turkish).

[5] Aldrich, J. H., Nelson, F. D. (1984): Linear Probability, Logit, and Probit Models. Thousand Oaks, CA: SAGE Publications, California, 95p.

[6] Alpar, R. (2011): Applied Multivariate Statistical Methods. - Detay Publishing, Ankara, 853p. (in Turkish).

[7] Anastasios, M., Koutsouris, A., Konstadinos, M. (2010): Information and communication technologies as agricultural extension tools: a survey among farmers in west Macedonia, Greece. - The Journal of Agricultural Education and Extension 16(3): 249-263.

[8] Anonymous (2004): Mugla Agriculture Master Plan. - Ministry of Agriculture and Rural Affairs, Muğla Province Directorate of Agriculture, Mugla.

[9] Anonymous (2017): Milas Agriculture and Forestry District Directorate Records. (in Turkish).

[10] Apantaku, S. O., Aromolaran, A. K., Shobowale, A. A., Sijuwola, K. O. (2016): Farmers and extension personnel view of constraints to effective agricultural extension services delivery in Oyo State, Nigeria. - Journal of Agricultural Extension 20(2). http://journal.aesonnigeria9.org/index.php/jae/article/view/869.

[11] Awino, O. I., Muya, S., Kabochi, S., Kutimaa, H., Kasina, M. (2018): Apiarists' awareness and responses to honey bee colony parasite and pathogen infections in Kenya. International Journal of Natural Resource Ecology and Management 3(4): 46-52.

[12] Boz, I., Akbay, C., Bas, S., Budak, D. B. (2011): Adoption of innovaitions and best manegement practices among dairy farmers in the eastern mediterranean region of Turkey. - Journal of Animal and Veterinary Advances 10(2): 251-261.

[13] Chambo, E. D., Garcia, R. C., Cunha, F., Carvalho, C. A. L., Caldas, M. J. M., da Silva, N. L. S., Ronqui, L., Junior, C. S., Santos, P. R., Toledo, V. A. A. (2018): Development of Beekeeping: An Analysis Using the Technique of Principal Components. - Chapter 4. In Insect Science-Diversity, Conservation and Nutrition.

[14] Cinemre, H. A., Demiryürek, K. (2005): Agricultural Extension and Communication. Ondokuz Mayıs University Agricultural Faculty Department of Agricultural Economics, Text Book No:17; Samsun, 150p. (in Turkish).

[15] Çukur, T., Çukur, F. (2017): Fair organizations from the participating firms in the agricultural fairs perspective and its contributions on the local economy: the case of Milas 2. south aegean agricultural fair. - Atatürk Univ. J. of the Agricultural Faculty 48(2): 9398. (in Turkish).

[16] Ertan, A., Gök, M. (2012): Analysis of the effective factors of Egirdir agricultural producers' decision process on having an agricultural insurance. - ODU Journal of Social Sciences Research 3(5): 66-76. (in Turkish).

[17] Everest, B. (2015): A Research on the Perception of Cooperative Principles and Analysis of Factors Affecting Member Participation in the Cooperative Management of Agricultural Credit Cooperatives: Case of Regional Union of Agricultural Credit Cooperative in 
Balıkesir. - Phd. thesis. Ege University Graduate School of Natural and Applied Science, Department of Agricultural Economics, İzmir. (in Turkish).

[18] Fadare, S. O., Ojo, S. O., Imoudu, P. B. (2008): Analysis of production performance of beekeeping in the niger delta area of Nigeria. - APIACTA 37-48.

[19] Gebremariam, G., Tesfaye, W. (2018): The heterogeneous effect of shocks on agricultural innovations adoption: Microeconometric evidence from rural Ethiopia. - Food Policy 74: 154-161.

[20] Hosmer, D. W., Lemeshow, S. (2000): Applied Logistic Regression. - Wiley-Interscience Publication, 392p.

[21] Ibegbulem, J. A. (2014): Evaluation of Honey from Some States in Nigeria by the Determination of Pollen Spectra, Physico-Chemical Parameters, Anti-Bacterial Activity and Consumers' Acceptance. - Phd thesis (unpublished). Department of Biological Sciences, Ahmadu Bello University, Zaria.

[22] Ijatuyi, E. (2016): Analysis of information sources used by fish farmers in Ife central local government area of Osun-State, Nigeria. - J. Hum. Ecol. 56(1-2): 91-98.

[23] Jan, I., Khan, H., Jalaluddin, M. (2008): Analysis of agricultural extension system: a discrepancy between providers and recipients of the extension services empirical evidence from north-west Pakistan. - Sarhad J. Agric. 24(2): 349-354.

[24] Jensen, L. P., Picozzi, K., de Almeida, O. C., da Costa, M. J., Spyckerelle, L., Erskine, W. (2014): Social relationships impact adoption of agricultural technologies: the case of food crop varieties in Timor-Leste. - Food Sec. 6: 397-409.

[25] Kenea, W. (2008): Rural Livelihood, Land Management and Biodiversity Community Participation for Biodiversity Conservation The case of Kakamega Forest in Western Kenya. - Phd thesis (unpublished). Fac. of Spatial Planning, Univ. of Dortmund.

[26] Kizilaslan, N. (2009): Attitudes and behaviors of the farmers towards agricultural extension (Tokat province research Yesilyurt county). - Tübav Science 2(4): 439-445. (in Turkish).

[27] Kizılaslan, N., Ünal, Y. (2013): Detection of farmers' awareness for agricultural extension (Tokat/Erbaa Case). - Gaziosmanpaşa Journal of Scientific Research 5: 1-19. (in Turkish).

[28] Klerks, L., van Mierlo, B., Leeuwis, C. (2012): Evolution of systems approaches to agricultural innovation: concepts, analysis and interventions. - In: Darnhofer, I., Gibbon, D., Dedieu, B. (eds.) Farming Systems Research into the 21st Century: The New Dynamic. Springer, Dordrecht, pp. 457-483.

[29] Kolade, O., Harpham, T. (2014): Impact of cooperative membership on farmers' uptake of technological innovations in Southwest Nigeria. - Development Studies Research 1(1): 340-353.

[30] Kumar, Y. (2013): A Multi-Dimensional Study on Production and Management System of Apiculture Farming in Jammu Region. - Phd thesis (unpublished). Division of Agricultural Extension Education, Sher-e-Kashmir University, Jammu.

[31] Longo, R. M. J. (1990): Information transfer and the adoption of agricultural innovations. - J. of The American Soc. for Information Sci. 41(1): 1-9.

[32] Muktar, B. G., Ahungwa, G. T., Nasiru, A. (2016): Farmers perception on the benefit of extension services in Jigawa State, Nigeria. - International Journal of Applied Research and Technology 5(8): 24-30.

[33] Mutsvangwa-Sammie, E. P., Manzungu, E., Siziba, S. (2018): Key attributes of agricultural innovations in semi-arid smallholder farming systems in south-west Zimbabwe. - Physics and Chemistry of the Earth 105: 125-135.

[34] Newbold, P. (1995): Statistics for Business and Economics. - Prentice-Hall International, New Jersey, 867p.

[35] Okwu, O. J., Iorkaa, T. I. (2011): An assessment of farmers' use of new information and communication technologies as sources of agricultural information in ushongo local government area, Benue state, Nigeria. - Journal of Sustainable Developmnet in Africa 13(2): 41-52. 
[36] Önder, H., Cebeci, Z. (2002): Variable Selection in Logistic Regression. - Journal of Çukurova University Agricultural Faculty 17(2): 105-114. (in Turkish).

[37] Özçatalbaş, O., Gürgen, Y. (1998): Agricultural Extension and Communication. - Baki Bookstore, Adana, 385p. (in Turkish).

[38] Özçatalbaş, N. (2000): An analysis of attitude and behaviours of farmers on agricultural information and extension in Şanliurfa province. - Journal of Mediterranean University Agricultural Faculty 13(2): 203-211. (in Turkish).

[39] Özkaya, T. (1996): Agricultural Extension and Communication. - Ege University Agricultural Faculty Publications No: 520, Ege University Agricultural Faculty Offset Printing, İzmir, 170p. (in Turkish).

[40] Pandey, D. K., De, H. K., Upadhaya, A. D. (2014): Information sourcing and utilisation by fish farmers of Tripura State in north-east India. - Indian J. Fish. 61(3): 99-103.

[41] Peter, B. G., Messina, J. P., Frake, A. N., Snapp, S. S. (2018): Scaling Agricultural Innovations: Pigeonpea in Malawi. - The Professional Geographer 70(2): 239-250.

[42] Rogers, E. M. (1976): New product adoption and diffusion. - J. of Consumer Res. 2(4): 290-301.

[43] Rogers, E. M. (1983): Diffusion of Innovations. - The Free Press, New York, 453p.

[44] Sezgin, A. (2010): Impact analysis of the mass media tools on the adoption of the innovations in animal production: the case of Erzurum province. - Journal of the Faculty of Veterinary Medicine, Kafkas University 16(1): 13-19. (in Turkish).

[45] Sezgin, A., Kaya, T., Külekçi, M., Kumbasaroğlu, H. (2010): Impact analysis on the adoption of the innovations generated for agricultural production: the case of Erzurum province. - IX Agricultural Economics Congress in Turkey, Şanlıurfa, 557-564p. (in Turkish).

[46] Siralı, R., Doğaroğlu, M. (2004): Determination of some occupational and sociological characteristics of Thracian beekeepers. - Uludag Bee Journal February: 35-41.

[47] TÜIKK (Turkish Statistical Institute) (2018): Livestock statistics. https://biruni.tuik.gov.tr/hayvancilikapp/hayvancilik.zul.

[48] Türkyılmaz, M. K., Bardakçıoğlu, H. E., Nazlıül, A. (2003): Socio-economic factors affecting the adoption of innovations in dairy enterprises in Aydın. - Turk J. Vet. Anim. Sci. 27: 1269-1275. (in Turkish).

[49] Udofia, S. I., Edet, I. B. (2016): Assessment of adoption level of beekeeping practices in Ikot Udo Abia community, Akwa Ibom State, Nigeria. - Nigerian J. of Agric., Food and Env. 12(4): 98-104.

[50] Wangu, K. C. (2014): Use of Social Media as a Source of Agricultural Information by Small Holder Farmers; A Case Study of Lower Kabete, Kiambu County. - Msc thesis (unpublished). School of Journalism and Mass Communication, University of Nairobi.

[51] Wodajo, W. A. (2011): Financial benefits of box hive and the determinants of its adoption in selected district of Ethiopia. - American J. of Economics 1(1): 21-29.

[52] Wossen, T., Abdoulaye, T., Alene, A., Haile, M. G., Feleke, S., Olanrewaju, A., Manyong, V. (2017): Impacts of extension access and cooperative membership on technology adoption and household welfare. - Journal of Rural Studies 54: 223-233.

[53] Yalçın, M., Boz, I. (2007): Information sources of greenhouse growers in Kumluca district. - Garden 36(1-2): 1-10. (in Turkish).

[54] Yigezu, Y. A., Mugera, A., El-Shater, T., Aw-Hassan, A., Piggin, C., Haddad, A., Khalil, Y., Loss, S. (2018): Enhancing adoption of agricultural technologies requiring high initial investment among smallholders. - Technological Forecasting \& Social Change 134: 199206.

[55] Yurttaş, Z., Atsan, T. (2007): Agricultural Extension and Communication Techniques. Atatürk University Agricultural Faculty Publications No: 67, Erzurum, 100p. (in Turkish). 